\title{
A tribute to Prof. T.N. Srinivasan, economist polymath by K.L. Krishna
}

\author{
K. L. Krishna ${ }^{1}$
}

Published online: 27 February 2019

(c) Editorial Office, Indian Economic Review 2019

This essay is a short tribute to Professor T.N. (Thirukodikaval Neelakanta) Srinivasan, referred to as "T.N." by his close academic associates. T.N. very sadly passed away in Chennai on November 10, 2018. I had known him since 1962 and interacted with him occasionally. Hundreds of his friends, professional colleagues, admirers all over the globe are mourning his loss. At the time of his death, Srinivasan was Samuel C. Park Jr. Professor of Economics (Emeritus) and Professor of International Area Studies (Emeritus) at Yale University. He was also Distinguished Professor, Department of Humanities and Social Sciences, at the Indian Institute of Technology (IIT), Madras since 2014. Though he was a permanent resident of USA, he remained an Indian Citizen, holding an Indian passport. This economist polymath had intimate knowledge of the economy, society and polity of India. This is amply reflected in his multitude of writings on Indian Economic Development and Public Policy. During the past 5 years or so, he mostly lived in Chennai and actively participated in seminars, conferences and workshops on various themes in development and growth. His scholarly presence and participation at such events made a big difference.

Srinivasan was born in 1933 in Tirupati, a temple town in Andhra Pradesh, then part of Madras Presidency, where his father was the District Munsiff. His ancestral village, Thirukodikaval is in Tanjore district of Tamil Nadu. He studied in Loyola College in Madras for his B.A. (Hons.) degree in Mathematics of the University of Madras obtained in 1953. He received Professional Training in Statistics at the Indian Statistical Institute (ISI), Calcutta, during 1953-1955. ISI was founded by Professor P. C. Mahalanobis in 1930s. The world-famous distinguished statistician, Professor C. R. Rao, was his teacher at ISI. Srinivasan held Professors Mahalanobis, C. R. Rao and Tjalling Koopmans, his doctoral supervisor in high regard. At ISI, he specialised in Operations Research (OR) and Statistical Quality Control (SQC), and worked as SQC officer during 1955-1957, before going to Yale University for Ph.D.

\section{K. L. Krishna}

krishna@econdse.org

1 Centre for Development Economics at Delhi School of Economics and Madras Institute of Development Studies, Chennai, India 
degree in Economics. Professor Tjalling Koopmans, a future Nobel Laureate, was his thesis supervisor. He completed his Ph.D. in 1962. His thesis was on Investment Criteria and Choice of Techniques of Production. He was on the research staff of the then-famous Cowles Foundation for Research in Economics, at Yale University during 1962-1964. ${ }^{1}$

After excellent training in Mathematics, Statistics and Economics at leading institutions in India and the United States, Srinivasan pursued his interests rigorously and vigorously in diverse branches of theoretical and applied economics, and made durable contributions in the areas of international trade, global integration, development economics and Indian economic development and policy, over a period of 55 years. In recent decades, the focus of his research was on links between trade, economic growth and poverty alleviation and on the reform of the International Financial Architecture so as to safeguard the interests of developing countries in general and the least developed countries (LDCs), in particular.

Srinivasan's CV running into some 30 pages, lists nearly 20 key positions held by him; ten awards and honours, several of them international; 30 books authored or edited by him, some ten of them on India specific; about 350 research articles published in leading journals or edited books, world over, including some 150 Indiaspecific papers. In addition, some 40 research papers were not published. ${ }^{2}$

Among TN's co-authors or co-editors, the prominent ones were Jagdish Bhagwati, V. K. Ramaswami, Holis Chenery, Jerry Beherman, J. Wallack, B.S. Minhas, Pranab Bardhan, Kirit Parikh, Aravind Panagariya, Suresh Tendulkar, Govinda Rao, Nirvikar Singh and G. S. Maddala. His academic output was not only phenomenal in quantity and quality but also very wide-ranging. He seemed to have missed no opportunity to delve into new areas in collaboration with even junior authors.

Srinivasan was a veritable source of inspiration to younger scholars. Professor N.S.S. Narayana who was TN's research student in ISI, Delhi, during 1970s, and who had retired a few years ago from ISI, Bengaluru, edited two volumes of Srinivasan's essays: the first volume in 2001 and the second in 2007. The first contained 21 papers on ten broad themes, all published originally before 1995 and the second contained 17 essays including the editor's introduction, originally published between 1995 and 2005. The two volumes taken together adequately cover Srinivasan's wideranging contributions prior to 2005. Srinivasan (2000) himself provides a good assessment of India's economic reforms undertaken in early 1990s. These eight lectures covering different sectors of the Indian economy have been widely cited by economists and policy analysts.

In a series of four invited lectures in July 2010 at the ICFAI University, Hyderabad, TN, covers economic growth and development in India during the six decades, 1950-2010. Srinivasan (2011) presents the material discussed in the four lectures together with comments of four economic policy experts, Lecture 1 relates to the License-Permit Raj era of 1950-1980; Lecture 2 deals with the events during

\footnotetext{
1 See (a) chapter 7: 'T.N. Srinivasan', in V.N. Balasubramanyam (2001), (b) Introduction in N.S.S. Narayana (ed. 2001) and (c) Introduction in N.S.S. Narayana (ed. 2007), for more details.

2 See the C.V. of T.N. Srinivasan, modified 12-08-2015, for full details.
} 
1981-1992, Lecture 3 analyses the major reforms and outcomes, during 1992-2008, including India's response to the Global Financial Crisis, while Lecture 4 covers the 2-year period 2008-2010, and addresses in a preliminary fashion the issue of sustainability of growth. The four lectures together is a valuable assessment of the Indian development experience and poverty eradication since independence. Lecture 4 attempts a useful comparison between India and China. In this lecture, Srinivasan argues that TFP (total factor productivity) growth is an indicator of sustainability of growth.

The links between trade liberalisation, economic growth and poverty eradication are the subject matter of many TN's research papers. Narayana (ed 2007) deals with this aspect. Srinivasan (2009) is a more recent extended analysis of this important theme with special reference to least developed countries (LDCs) and some other groupings of developing countries.

Srinivasan (2009) deals in Chapter 4 with cooperation between developed and developing countries to strengthen the links between Trade, Growth and Poverty Reduction. Section 2 in chapter 6 presents Srinivasan's recommendations for making global partnership for development more effective. These include suggestions for the reform of the World Bank and IMF to safeguard the interests of developing countries.

In Srinivasan et al. (2017), based on Srinivasan's Indian Economic Review Distinguished Lecture delivered in February 2017 at the Delhi School of Economics, the issue of morbidity in India since 1944, using appropriate statistical and econometric methods and recent data was discussed.

Menon and Srinivasan (eds, 2018) was perhaps the last major contribution of Srinivasan. He was the first author of the Introduction to the volume of ten essays divided into three sections on the important theme of integration between South and East Asia. The collection throws much useful light on the progress of integration and related aspects.

Professor T.N. Srinivasan was a highly gifted and accomplished world-class economist with very wide interests in analytical and public policy issues. He was a prolific author and incisive thinker, an eloquent and intrepid advocate of fairness in international economic relations with focus on poverty eradication. His championship of global integration and economic cooperation between developed and developing countries was indeed laudable.

Professor Srinivasan was deeply attached to India and spent his last years in Chennai. He was an ardent lover of Carnatic Music and a Sanskrit Scholar. TN led an ascetic life, against superstition and rituals. ${ }^{3}$ He was a humanist and a rare human being. He will be missed greatly by all who knew him.

\section{References}

Balasubramanyam, V. N. (2001). Conversations with Indian Economists. New York: Palgrave. Banerjee, A. (2018). Let Raag Bhairav accompany you. Delhi: The Indian Express.

\footnotetext{
${ }^{3}$ See Banerjee (2018).
} 
Menon, Jayant, \& Srinivasan, T. N. (2018). Integrating south and east Asia: Economics of regional cooperation and development. New Delhi: OUP.

Narayana, N.S.S. (2001, ed.). Economic Policy and State Intervention: selected papers of T.N. Srinivasan. New Delhi: OUP.

Narayana, N.S.S. (2007, ed.). The political economy of trade, finance and development: selected essays of T.N. Srinivasan. New Delhi: OUP.

Srinivasan, T. N. (2000). Eight lectures on India's economic reforms. New Delhi: OUP.

Srinivasan, T.N. (2009). Trade, Growth and Poverty Reduction. London: Commonwealth Secretariat and New Delhi: Academic Foundation.

Srinivasan, T. N. (2011). Growth, sustainability and India's economic reforms. New Delhi: OUP.

Srinivasan, T. N., et al. (2017). Morbidity in India since 1944. Indian Economic Review, 52(1-2), 3-35.

Publisher's Note Springer Nature remains neutral with regard to jurisdictional claims in published maps and institutional affiliations. 